Pedagogical Technology of PhD Students' Effective Self-Management. The new educational review, 2 (56). 53-65. Toruń: Wydawnictwo Adam Marszałek. URL: https://tner.polsl.pl/dok/volumes/tner_2_2019b.pdf [in Inglish].

Mika, S. (1981). Psychologia społeczna. Warszawa: PWN [in Polish].

Nęcka, Z. (1992). Komunikowanie interpersonalne. Wrocław: Ossolineum [in Polish]. Reich, T., Hershcovis, S. (2011). Interpersonal relationships at work. In book: Handbook of industrial and organizational psychology, 3, 223-248. DOI:10.1037/12171-006 [in Inglish].

Sillamy, N. (1995). Słownik psychologii. Katowice: Książnica [in Polish].

Szewczuk, W. (1979). (red.) Słownik psychologiczny. Warszawa, Wiedza Powszechna [in Polish].

Szmagalski, J. (1998). Przewodzenie małym grupom. Działanie grupowe. Warszawa: Centrum Animacji Kultury [in Polish].

УДК [37.011.3-051:373(477)]: 316.645[377-043.86]

DOI: https://doi.org/10.35387/od.2(20).2021.168-176

$\begin{array}{lll}\text { Хомич лідія Олексіївна - } & \text { Khomych Lidia - Doctor of } \\ \text { доктор педагогічних наук, } & \text { Pedagogical Sciences, Professor, } \\ \text { профресор, заступник директора } & \text { Deputy Director for Research at the } \\ \text { з наукової роботи Iнституту } & \text { Ivan Ziaziun Institute } \\ \text { педагогічної освіти i освіmи } & \text { of Pedagogical and Adult } \\ \text { дорослих імені Івана Зязюна } & \text { Education of the NAES of Ukraine }\end{array}$
НАПН України

ORCID iD: https://orcid.org/0000-0003-1130-4395

E-mail:ukrlida@ukr.net

\title{
ВЧИТЕЛЬ НОВОЇ УКРАЇНСЬКОЇ ШКОЛИ: ВЕКТОРИ ПРОФЕСІЙНОГО РОЗВИТКУ
}

\begin{abstract}
Анотація. У статmі автором проаналізовано проблему профресійного розвитку вчителя нової української школи. Актуальність досліджуваної проблеми визначається концептуальними підходами обґрунтованими у законодавчих документах про освіту, зокрема Концепцією Нової української школи. В умовах її впровадження важливо вдосконалювати підготовку майбутніх вчителів у закладах педагогічної освіти, а також сприяти професійному розвитку працюючого вчителя. Вектори профресійного розвитку вчителя НУШ визначені з урахуванням концептуальних засад реформування сучасного освітнього простору та впровадження педагогічних інновацій в освітню діяльність. Вони визначають потреби вчителя НУШ: оволодівати новими фрункціями які пов'язані зі зміною ролі вчителя; бути фрасилітатором, тьютером, коучем в освітній діяльності; бути наставником, який готовий ділитися з учнем власним досвідом; бути новатором, використовувати новітні технології та сучасні практики в навчанні учнів; орієнтуватися в інформаційному освітньому просторі. Профресійний розвиток вчителя, як відомо, здійснюється у системі
\end{abstract}


формальної, неформальної та інформальної післядипломної освіти. Доведено, що прагнення до самовдосконалення, самоосвіта $\epsilon$ важливими чинниками профресійного зростання вчителя, забезпечує розвиток його творчих можливостей, пізнавальних інтересів та фрормування творчої індивідуальності.

Ключові слова: вчитель; професійний розвиток вчителя; Концепція Нової української школи; фрункції вчителя; освітня діяльність; самоосвіта вчителя.

\section{Khomych Lidiia}

\section{TEACHER OF THE NEW UKRAINIAN SCHOOL: VECTORS OF PROFESSIONAL DEVELOPMENT}

Abstract. In the article the author analyzes the problem of professional development of a teacher of a new Ukrainian school. The relevance of the researched problem is determined by the conceptual approaches substantiated in the legislative documents on education, in particular by the Concept of the New Ukrainian School. In terms of its implementation, it is important to improve the training of future teachers in pedagogical education institutions, as well as to promote the professional development of working teachers. Vectors of professional development of NUS teachers are determined taking into account the conceptual foundations of reforming the modern educational space and the introduction of pedagogical innovations in educational activities. They determine the needs of the NUS teacher: to master new functions that are associated with changing the role of the teacher; to be a facilitator, tutor, coach in educational activities; be a mentor who is willing to share his own experience with the student; be an innovator, use the latest technologies and modern practices in teaching students; navigate in the information educational space. The teacher professional development is known to be carried out in the system of formal, non-formal and informal postgraduate education. It is proved that the desire for self-improvement, self-education are important factors in the professional growth of teachers, ensures the development of his creative abilities, cognitive interests and the formation of creative personality.

Key words: teacher; professional development of a teacher; Concept of the New Ukrainian school; functions of a teacher; educational activity; self education of a teacher.

Постановка проблеми, їі актуальність. У Концепції нової української школи зазначається, що школа потребує вчителя, який зможе стати агентом змін, бути творчим і відповідальним, постійно працювати над собою. У зв'язку з цим варто говорити про нову роль вчителя - не як єдиного наставника та джерело знань, а як коуча, фасилітатора, тьютера, модератора в індивідуальній освітній траєкторії розвитку дитини (Концепція нової української школи, 2016).

Міністр освіти і науки України зазначає - «Складовою реформи «Нова українська школа» $€$ підготовка нового вчителя. Учитель Нової української школи - це людина, на якій тримається рефрорма. Без неї чи нього будь-які зміни будуть неможливими, тому один з головних принципів 
Нової української школи - умотивований учитель. Це означає, що наша мета - сприяти його професійному та особистому зростанню, а також підвищувати його соціальний статус» (С. Шкарлет, 2021).

Отже, вчитель - візитівка реформи, головний рушій змін. Тому умотивований, готовий до змін власного мислення педагог, що володіє новітніми компетенціями та інструментами - головна мета НУШ. Її ж пріоритет - забезпечити професійне й особисте зростання вчителя, підвищити соціальний статус. Аби вони надихались самі й надихали інших (Вчитель НУШ - людина, яка надихає вчитися, 2020).

За таких умовах для освіти і науки важливо відійти від застарілих теорій і авторитарного педагогічного досвіду. У публікаціях щодо освітньої реформи, учитель Нової української школи (НУШ) повинен розвивати дитину і створювати атмосферу, в якій цікаво, в якій дитина хоче навчатися. Зазначається також, що потрібно відірвати вчителя від дошки, а дітей - від підручника, дати їм можливість творити і самостійно вчитися, працювати в групах, розвивати пізнавальний інтерес та заохочувати до навчання, тобто від усього застарілого в учителя має залишитися роль лідера, але такого, який не нав'язує, а організовує і координує весь освітній процес, перевага в якому надається різнобічному розвиткові, формуванню особистості, інноватора та патріота (Черній А, 2018).

Це узгоджується з думкою В.Кременя, що перехід до нової парадигми освіти характеризується зміщенням основного акценту із засвоєння певного обсягу інформації на активізацію мисленнєвої діяльності та розвиток самостійного, критичного і саморефлексивного мислення. У своїх публікаціях і виступах зазначає, що в цьому полягає суть нової фрілософії освіти. Отже, вища освіта не є сталим процесом здобуття знань, умінь, навичок на все життя, а уособлює формування умінь здобувати знання самостійно. Можна констатувати: в сучасних умовах потрібен вчитель не лише з вищою освітою, а насамперед, фахівець, який творчо мислять, генерує нові ідеї, уміє спілкуватися і працювати в команді, гнучкий і упевнені в собі.

В умовах впровадження Концепції НУШ важливо не тільки вдосконалювати підготовку майбутніх вчителів у закладах передвищої і вищої педагогічної освіти, а й сприяти професійний розвиток працюючого вчителя.

Аналіз актуальних досліджень і публікацій. Проблемі профресійного розвитку вчителя присвячено широкий спектр наукових досліджень. Філософські аспекти неперервної педагогічної освіти представлено в роботах В. Андрущенка, І. Зязюна, В.Кременя та ін. Неперервну професійну освіту 3 урахуванням світових тенденцій, інноваційних підходів і принципів освіти дорослих висвітлено у працях С. Гончаренка, О. Дубасенюк, А. Кузьмінського, Л. Лук'янової, Н. Ничкало С. Сисоєвої та ін. Особливості інтеграції вищої і післядипломної освіти України у європейський освітній простір досліджено у працях Н. Авшенюк, М. Лещенко, О. Огієнко, Л. Пуховської та ін. Професійну самоосвіту і самовиховання у наукових дослідженнях О. Коношевського, О. Кучерявого, М. Солдатенка та ін. Професійний розвиток вчителя в умовах нової української школи досліджують Ю. Бурцева, О. Вознюк, О. Дубасенюк, 
С. Мірошник, М. Скиба, А. Черній та ін.

Актуальним $€$ твердження І. А. Зязюна, що головною метою педагогічної освіти має бути підготовка вчителя, який володіє необхідними творчими й професійними якостями, що дають йому змогу творити педагогічну дію для найбільш продуктивного розвитку різновидів досвіду учнів, передусім теоретичного, почуттєвого (естетичного), практичного для гармонійного особистісного розвитку кожного учня (Концептуальні підходи до розвитку багаторівневої педагогічної освіти в Україні, 2011).

Цінним $є$ накопичений європейськими країнами досвід післядипломної освіти вчителів для осмислення і творчого використання українськими педагогами в умовах оновлення системи післядипломної освіти педагогів в Україні. Для професійного розвитку вчителів важлива, зокрема: централізація та децентралізація в управлінні системою педагогічної освіти для диверсифікація типів провайдерів професійного розвитку вчителів за рахунок професійних спілок працівників освіти, центрів з підготовки вчителів, освітніх асоціацій України; реалізація неперервного професійного розвитку вчителів за чітко визначеними стратегіями, етапами та напрямами удосконалення; активізація професійного зростання вчителів з використанням новітніх інформаційних технологій та всесвітньої електронної мережі Інтернет; співпраця між органами освіти, громадськими, освітніми і професійними національними та міжнародними об'єднаннями 3 метою обміну досвідом, реалізації масштабних проектів та програм, урізноманітнення форм професійного розвитку вчителів із залученням неформальних провайдерів професійного розвитку; мотивація вчителів до активного професійного зростання (Зарубіжний досвід професійної підготовки педагогів, 2017, с. 77-80).

Основні кроки щодо розв'язання проблеми формування нового вчителя для об'єднаної Європи XXI століття схарактеризовані В. Андрущенком, зокрема він наполягає на потребі визначення та формування єдиної шкали цінностей для підготовки вчителя в країнах Європи, на основі якої і будуть створюватися навчальні плани, програми, підручники й посібники (Андрущенко, 2012). Саме загальнолюдські цінності $\epsilon$ основою педагогіки партнерства, мають реалізуватися у змісті професійної підготовки вчителя, а також сприяти гуманній взаємодії в освітньому середовищі.

Мета статті полягає у визначенні та обґрунтуванні напрямів професійного розвитку вчителя НУШ.

Виклад основного матеріалу дослідження. Упровадження Концепції НУШ - це процес, під час якого вчитель переглядає, оновлює, розширює свої зобов'язання щодо моральної мети викладання, критично розвиває знання, уміння, досконале професійне мислення, планування i практику роботи з дітьми, учнівською молоддю й колегами на сучасному етапі свого професійного життя. 3 цією метою, у Концепції розвитку педагогічної освіти в Україні запропоновано створити національний портал розвитку педагогічної майстерності вчителя, завдяки якому освітяни мали б вільний доступ до професійних журналів та інших ресурсів (Концепція розвитку педагогічної освіти в Україні, 2018). 
Таким чином, проблема професійного розвитку вчителя не $є$ новою, на всіх етапах суспільного розвитку вона актуалізувалась. В Україні питання реформування освіти, зокрема педагогічної, розпочались на початку XXI століття. Зокрема, науковцями виокремлено п'ять концептуальних засад, у площині яких професійний розвиток особистості педагога $є$ актуальним та вимагає поглибленого дослідження, серед них: 1. Загальноцивілізаційні, які зумовлюються соціальним замовленням сучасного суспільства на компетентного фахівця; 2. Діяльнісно-особистісні, що передбачають входження людства в еру інфрормаційного суспільства i докорінну зміну умов навчання і виховання; 3. Системно-наукові й методологічні, що позначається на зміні наукової парадигми пізнання та освоєння світу; 4. Розвивально-профресіографрічні, що зумовлюються загальнонауковими закономірностями розвитку людини і передбачають неперервне становлення вчителя-професіонала; 5. Парадигмальні, які зумовлюються зазначеною вище докорінною загальноцивілізаційною трансформацією сучасного життя, яке знаменується кризою сучасної системи освіти (Вознюк, 2009).

Науковці професійний розвиток вчителя, як правило, пов'язують із його профресійним зростанням та формуванням професіоналізму. В умовах НУШ це потребує: по-перше, усвідомлення вчителем усіх перетворень в освіті; по-друге, систематичного підвищення своєї кваліфікації, розвитку професійного світогляду і педагогічної свідомості; по-третє, удосконалення практичного досвіду і перегляду власних підходів до викладання й педагогічної взаємодії. У дослідженнях зазначається, що вчителеві НУШ необхідно знати свої «слабкі» та «сильні» особливості, постійно формувати внутрішній стрижень особистісного зростання як необхідної умови для досягнення професіоналізму. Тому професіоналізм, як психологічне й особистісне утворення, характеризується не лише професійними знаннями, уміннями, навичками та компетентностями, а й мистецтвом постановки, пошуку підходів для виконання професійних завдань (Черній, 2018).

В умовах, коли змінюється освітня стратегія, професійна компетентність учителя набуває надзвичайної актуальності. У Концепції НУШ визначено ключові компетентності для життя, які вчитель має усвідомити, прийняти і відповідно здійснювати педагогічну діяльність. Це актуалізує проблему підготовки вчителя, його професійного становлення і профресійної компетентності, як динамічного поєднання знань, умінь і способів педагогічної дії. Саме компетентнісний підхід $\epsilon$ одним із важливих концептуальних принципів оновлення теорії і практики педагогічної освіти. Визначені основні компетентності, якими має володіти вчитель XXI століття: 1) комунікативна; 2) самоідентичності; 3) справедливості; 4) лідерська; 5) дослідницькоаналітична; 6) здатність навчатися протягом життя; 7) емпатія - здатність розуміти переживання учня чи студента та співпереживати в процесі спілкування (Педагогічна Конституція Європи, 2013, с. 116).

На думку І. Зязюна, «складниками професіоналізму у будь-якій професії $є$ компетентність та озброєння системою вмінь» (Педагогічна майстерність, 1997, с. 112). Профресійна компетентність аналізується 
багатьма дослідниками як сукупність особистісних якостей, знань, умінь, що забезпечують високий рівень самоорганізації профресійної діяльності, іï результатів, самопізнання та саморозвиток. Отже, це складне системне утворення, що є основою професійної діяльності вчителя, його майстерності і творчості. У вчителя, перш за все мають фрормуватися компетентності, що визначені Законом України «Про освіту»: комбінація знань, умінь, навичок, способів мислення, поглядів, цінностей, інших особистих якостей.

У професійному стандарті вчителя за професіями «Вчитель початкових класів закладу загальної середньої освіти», «Вчитель закладу загальної середньої освіти», «Вчитель з початкової освіти (з дипломом молодшого спеціаліста)» визначені і обґрунтовані професійні компетентності якими повинен володіти вчитель (Реєстр професійних стандартів, 2021). Основна ідея стандарту - особистісний і професійний вимір діяльності вчителя закладу загальної середньої освіти. Відповідно визначені функції вчителя НУШ: усвідомлення і дотримання загальнолюдських цінностей життєдіяльності людини; партнерська взаємодія з колегами, учнями, батьками, громадськістю; формування гуманного, комфортного для учня освітнього середовища; планування різних видів діяльності; підтримка навчання та розвитку учня; організація виховної роботи з учнями; методична робота з предмету; оцінювання навчальних досягнень учня; рефрлексія та професійний саморозвиток; педагогічні дослідження, узагальнення власного досвіду роботи.

Таким чином, вектори професійного розвитку вчителя НУШ можна визначити враховуючи концептуальними засадами реформування сучасного освітнього простору та впровадження педагогічних інновацій в освітню діяльність. Вчитель - за словами Міністра освіти і науки України - отримав свободу не лише навчати, а й свободу навчатися» (Шкарлет, 2021). Окреслимо найбільш актуальні вектори професійного розвитку вчителя НУШ, що визначають його потреби.

По-перше, оволодівати новими функціями які пов'язані зі зміною ролі вчителя - бути не передавачем знань, а навчати вчитися. Справжній вчитель той, який постійно навчається і у якого хочеться вчитися, наслідувати його. Тобто це наставник, який вміє організувати процес пізнання учнями нового. Вчителю самому має бути цікаво вчитися, тоді він знайде спосіб зацікавити учнів.

По-друге, бути фасилітатором, тьютером, коучем в освітній діяльності, відповідно: забезпечувати ефективну групову комунікацію учнів; сприяти формуванню цілісної особистості учня, розвитку його інтелекту, волі, емоцій, фрізичного і духовного стану; допомагати учням досягти поставленої мети. У цьому контексті важливо сформувати в учнів так звані «м'які навички», такі як, вміння долати труднощі, знаходити рішення, ставити цілі та докладати зусилля для їх досягнення, наполегливість, комунікативність тощо.

По-третє, бути наставником, який готовий ділитися з учнем власним досвідом, вміти вводити його в коло своїх інтересів. В той же час, розуміти учня, говорити з повагою до нього, реалізувати індивідуальну освітню траєкторію його розвитку, що $€$ одним із головних завдань 
Концепції НУШ.

По четверте, бути новатором, використовувати новітні технології та сучасні практики в навчанні учнів, уміти створювати розвивальне освітнє середовище.

По-п'яте, орієнтуватися в інформаційному освітньому просторі, отримувати інформацію та використовувати її відповідно до власних потреб і вимог сучасного високотехнологічного інформаційного суспільства.

Беручи до уваги визначені у законодавчих документах основи професійного розвитку вчителя, зазначимо, що він реалізується як у системі формальної, нефрормальної та інформальної післядипломної освіти (спеціалізованих закладах, закладах вищої педагогічної освіти і наукових установах), так і неперервного професійного саморозвитку. Діяльність установ післядипломної освіти спрямовується на психологопедагогічну підготовку вчителів до роботи у нових соціально-економічних умовах, впровадження нових педагогічних технологій.

3 метою вдосконалення професійного розвитку вчителя НУШ, заклади і установи постійно розширюють спектр пропонованих освітніх програм, зокрема впроваджуються дистанційні курси, спрямовані на формування та розвиток ключових компетентностей учителя НУШ; забезпечують необхідні умови для неперервного професійного розвитку вчителів за чітко визначеними стратегіями.

Професійний саморозвиток вчителя - неперервний процес індивідуального навчання. Прагнення до самовдосконалення, самоосвіта $€$ важливими чинниками профеесійного зростання вчителя, що забезпечують розширення його творчих можливостей, пізнавальних інтересів та формування творчої індивідуальності. Важливе значення для професійного зростання вчителя мають: ознайомлення 3 досвідом роботи вчителівноваторів НУШ; здійснення дослідно-експериментальної роботи у процесі своєї освітньої діяльності; вивчення фрілософської та психологопедагогічної літератури, законодавчих актів держави про освіту, виховання та навчання; участь у роботі методичних об'єднань, семінарів, вебінарів, конфреренцій, педагогічних читань та інше.

У процесі професійного саморозвитку вчитель має відчути свободу самовираження. Лише за умов професійної свободи можлива ефективна організація процесу професійного зростання вчителя, що є своєрідним пошуком свого шляху, набуття власного досвіду. Вчитель, що володіє свободою самовираження, вміє керувати власним розвитком, може спрямувати свої творчі сили на пошук нових шляхів навчання і виховання учнів.

Висновки та перспективи подальших досліджень. Отже, мають бути осучаснені вектори професійного розвитку вчителів НУШ шляхом насичення його відомостями про сутність трансформаційних процесів у світовій і вітчизняній освіті, про сучасні педагогічні, дидактичні, методичні системи, в основу яких покладено інформаційно-комунікаційні технології. Вчитель НУШ має володіти найвищим рівнем педагогічної майстерністі, культурою спілкування, бути глибоко обізнаним 3 дидактичними можливостями комп'ютерної техніки й ефективно їх використовувати в освітньому процесі. Для ефективного здійснення профресійної діяльності і 
розвитку педагогічної творчості необхідно постійно вдосконалювати психолого-педагогічну і методичну підготовку вчителя НУШ.

Діяльність закладів післядипломної освіти необхідно спрямувати на розроблення і впровадження нових технологій та заходів щодо вдосконалення професійного розвитку вчителів, з цією метою: необхідно удосконалити освітні програми на основі використання інформаційних технологій; створювати та здійснювати апробацію нового змісту профресійного розвитку вчителя НУШ; передбачити у фаховому вдосконаленні вчителів формування готовності до роботи в НУШ та здатності їх до реалізації компетентнісного підходу в освітній діяльності.

\section{Список використаних джерел}

Андрущенко, В. (2012). Проблема формування нового вчителя для об'єднаної Європи XXI століття. Європейські педагогічні студії. Асоціація ректорів педагогічних університетів Європи : зб. статей / ред. кол. В. Андрущенко (голова). 1-2. Київ : Вид-во КНПУ ім. М. Драгоманова.

Вознюк, О.В., \& Дубасенюк О.А. (2009). Цільові орієнтири розвитку особистості у системі освіти: інтегративний підхід: Монографія. Житомир: Вид-во ЖДУ ім. І. Франка.

Вчитель НУШ - людина, яка надихає вчитися. (2021). URL: http://osvita.ua/school/71971/

Зарубіжний досвід професійної підготовки педагогів: аналітичні матеріали (2017). [Авшенюк, Н.М., Дяченко, Л.М., Котун, К.В., Марусинець, М.М., Огієнко, О.І., Сулима, О.В., Постригач, Н.О.]. Київ : ДКС «Центр».

Концепція нової української школи (2016). URL: https://www.kmu.gov.ua/storage/app/media/reforms/ukrainska-shkolacompressed.pdf

Концепція розвитку педагогічної освіти в Україні. (2018). URL: https://mon.gov.ua/ua/npa/pro-zatverdzhennya-koncepciyi-rozvitkupedagogichnoyi-osviti

Концептуальні підходи до розвитку багаторівневої педагогічної освіти в Україні (2011). НПУ імені М.П. Драгоманова, Київ.

Педагогічна Конституція Європи. (2013). Вища освіта України. 3.

Педагогічна майстерність. (1997). [І. А. Зязюн, Л. В. Карамущенко, І. Ф. Кривонос та ін.] ; за ред. І. А. Зязюна. К. : Вища школа.

Реєстр професійних стандартів Міністерства розвитку економіки, торгівлі і сільського господарства. (2021). URL: https://www.me.gov.ua/Documents/Detail

Черній, А. (2018). Професійний розвиток педагога: досвід, співпраця, пріоритети на шляху до нової української школи. URL: httpumo.edu.uaimagescontentnashi_vydanyapislya_dyplom_osvina2_2018.pdf Шкарлет, С. (2021). Учитель нової української школи - це людина, на якій тримається реформа. URL: https://mon.gov.ua/ua/news/sergij-shkarletuchitel-novoyi-ukrayinskoyi-shkoli-ce-lyudina-na-yakij-trimayetsya-reforma

\section{References (translated and transliterated)}

Andrushchenko, V. (2012). Problema formuvannya novoho vchytelya dlya ob"yednanoï Yevropy XXI stolittya [The problem of forming a new teacher for a united Europe in the 21st century]. Yevropey̆s'ki pedahohichni studiï. 
Asotsiatsiya rektoriv pedahohichnykh universytetiv Yevropy - European Pedagogical Studies. Association of Rectors of European Pedagogical Universities: V. Andrushchenko (Eds.). 1-2. Kyiv: KNPU Publishing House. M. Drahomanova [in Ukrainian].

Vozniuk, O.V., Dubaseniuk O.A. (2009). Tsilovi oriientyry rozvytku osobystosti u systemi osvity: intehratyvnyi pidkhid : Monohrafiia [Targets of personality development in the education system: an integrative approach]. Zhytomyr: Vyd-vo ZhDU im. I. Franka [in Ukrainian].

Vchytel NUSh - liudyna, yaka nadykhaie vchytysia [A NUS teacher is a person who inspires learning]. (2021). URL: http://osvita.ua/school/71971/ [in Ukrainian].

Zarubizhnyi dosvid profesiinoi pidhotovky pedahohiv: analitychni materialy [Foreign experience of professional training of teachers: analytical materials]. (2017) [Avsheniuk N.M., Diachenko L.M., Kotun K.V., Marusynets M.M., Ohiienko O.I., Sulyma O.V., Postryhach N.O.]. Kyiv : DKS «Tsentr» [in Ukrainian].

Kontseptsiia novoi ukrainskoi shkoly [The concept of a new Ukrainian school]. (2016). URL: https://www.kmu.gov.ua/storage/app/media/reforms/ ukrainska-shkola-compressed.pdf [in Ukrainian].

Kontseptsiia rozvytku pedahohichnoi osvity $v$ Ukraini [The concept of development of pedagogical education in Ukraine]. (2018). URL: https://mon.gov.ua/ua/npa/pro-zatverdzhennya-koncepciyi-rozvitkupedagogichnoyi-osviti [in Ukrainian].

Kontseptualni pidkhody do rozvytku bahatorivnevoi pedahohichnoi osvity v Ukraini [Conceptual approaches to the development of multilevel pedagogical education in Ukraine]. (2011). NPU imeni M.P. Drahomanova, Kyiv [in Ukrainian].

Pedahohichna Konstytutsiia Yevropy [Pedagogical Constitution of Europe]. (2013). Vyshcha osvita Ukrainy - Higher education in Ukraine. 3 [in Ukrainian].

Pedahohichna maisternist [Pedagogical skills]. (1997). [I.A. Ziaziun, L.V. Karamushchenko, I. F. Kryvonos ta in.]; I.A. Ziaziun (ed.). K. : Vyshcha shkola - High school [in Ukrainian].

Reiestr profesiinykh standartiv Ministerstva rozvytku ekonomiky, torhivli i silskoho hospodarstva [Register of professional standards of the Ministry of Economic Development, Trade and Agriculture]. (2021). URL: https://www.me.gov.ua/Documents/Detail [in Ukrainian].

Chernii, A. (2018). Profesiinyi rozvytok pedahoha: dosvid, spivpratsia, priorytety na shliakhu do novoi ukrainskoi shkoly [Professional development of a teacher: experience, cooperation, priorities on the way to a new Ukrainian school]. URL: httpumo.edu.uaimagescontentnashi_vydanyapislya_dyplom_ osvina2_2018.pdf [in Ukrainian].

Shkarlet, S. (2021). Uchytel novoi ukrainskoi shkoly - tse liudyna, na yakii trymaietsia reforma [The teacher of the new Ukrainian school is the person on whom the reform rests]. URL: https://mon.gov.ua/ua/news/sergijshkarlet-uchitel-novoyi-ukrayinskoyi-shkoli-ce-lyudina-na-yakij-trimayetsyareforma [in Ukrainian]. 
УДК 005.336.2

DOI: https://doi.org/10.35387/od.2(20).2021.177-187

Шакун Наталія Андріївна аспірантка Національного університету біоресурсів $i$ природокористування України
Shakun Nataliia - Graduate Student of the National University of Life and Environmental Sciences of Ukraine

ORCID iD: $h$ ttps://orcid.org/0000-0002-4233-168X

E-mail: tatkashakun@gmail.com

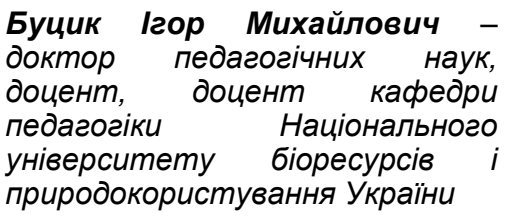

Butsyk Ihor - Doctor of Pedagogical Sciences, Associate Professor, Associate Professor of the Pedagogy Department of the National University of Life and Environmental Sciences of Ukraine

ORCID iD: https://orcid.org/0000-0002-3105-2802

E-mail: i_butsyk@ukr.net

\section{ЗМІСТ I СУТНІСТЬ ПРОФОРІЄНТАЦІЙНОЇ КОМПЕТЕНТНОСТІ ВИКЛАДАЧА ЗАКЛАДУ ВИЩОЇ ОСВІТИ}

Анотація. В оглядовій статті розглядається проблема визначення змісту та сутності профорієнтаційної компетентності викладача закладу вищої освіти в контексті підготовки його до здійснення профоорієнтаційної роботи, передбаченими професійними завданнями щодо залучення абітурієнтів до вступу. Виділено потребу та основні завдання профрорієнтаційної діяльності викладача закладу вищої освіти з орієнтирами на професійний стандарт.

У результаті проведеного авторами аналізу наукових праць виокремлено загальні характерні складові профрорієнтаційної компетентності, що дозволило їі розглядати як інтегровану якість особистості, об'єднану готовністю й здатністю до здійснення цілеспрямованої профорієнтаційної діяльності з майбутніми вступниками на основі попередньо сфрормованих знань, умінь, навичок, якостей, інтересів $i$ цінностей.

Авторами публікації пропонуються узагальнені результати аналізу наукових поглядів у даному напрямі, на основі чого виокремлено у змісті профорієнтаційної компетентності викладача закладу вищої освіти інтегровані компоненти (когнітивний, мотиваційно-ціннісний, діяльнісний та особистісно-рефрлексивний), які характеризуються сфрормованістю знань, умінь, навичок та якостей особистості, які покладено в основу ефрективної профорієнтаційної роботи. У результаті проведеного дослідження авторами уточнено сутність поняття «профорієнтаційна компетентність викладача закладу вищої освіти».

Ключові слова: компетентність; профоорієнтаційна діяльність; профорієнтаційна компетентність; викладач закладу вищої освіти; здатність особистості. 